\title{
A New Species of the Commensal Crab Genus Aphanodactylus (Crustacea : Brachyura: Pinnotheridae) from the Yaeyama Islands, Southern Japan
}

\author{
$\operatorname{AUTHOR}(S)$ :
}

Konishi, Kooichi; Noda, Hirokuni

\section{CITATION:}

Konishi, Kooichi ...[et al]. A New Species of the Commensal Crab Genus Aphanodactylus (Crustacea: Brachyura: Pinnotheridae) from the Yaeyama Islands, Southern Japan. PUBLICATIONS OF THE SETO MARINE BIOLOGICAL LABORATORY 1999, 38(5-6): 223-229

\section{ISSUE DATE:}

\section{9-09-30}

URL:

http://hdl.handle.net/2433/176286

RIGHT: 


\title{
A New Species of the Commensal Grab Genus Aphanodactylus (Crustacea: Brachyura: Pinnotheridae) from the Yaeyama Islands, Southern Japan
}

\author{
KOOICHI KONISHI ${ }^{1)}$ \& HiroKUNI NoDA ${ }^{2)}$ \\ 1) National Research Institute of Aquaculture, Nansei, Mie, 516-0193 Japan \\ ${ }^{2)}$ Department of Biology, Tokyo Women's Medical University, Shinjuku, \\ Tokyo, 162-8666 Japan
}

\begin{abstract}
A new commensal crab, Aphanodactylus loimiae, is described from the Yaeyama Islands, Okinawa Prefecture, Japan. The present species is the third species of this rare pinnotherid genus. It differs from the two previously known species in carapace shape, number of segments of anntennal flagellum, and number of merus teeth on walking legs. The single specimen was found in the tube of a sessile polychaete, Loimia ingens Grube. A dichotomous key and a diagrammatic key to the subfamilies of the Pinnotheridae and the genera of the Asthenognathinae in Japan are given.
\end{abstract}

Key words: Crustacea, Pinnotheridae, Aphanodactylus, Polychaeta, Loimia, key, new species, taxonomy

Since the description of Pinnotheres pholadis in the "Fauna Japonica" by de Haan (1835), the pinnotherid crab fauna of Japan has come to include 31 species in 13 genera (Sakai, 1976; Miyake, 1983; Konishi, 1996). Most of the work, however, has been focused on the subfamily Pinnotherinae, with relatively little attension directed toward other subfamilies, e.g., the Asthenognathinae. At present, the Asthenognathinae consists of seven genera in the world, two of which, Asthenognathus and Tritodynamia, have been known from Japan. The genus Aphanodactylus was proposed by Tesch (1918), with the description of a new species, $A$. sibogae, from Sumbawa Island, Indonesia. Another species, A. edmondsoni was described by Rathbun (1932) from the Hawaiian Islands. No other records of Aphanodactylus crabs have been published. A single specimen of a small pinnotherid crab, representing the genus Aphanodactylus, but differing morphologically from the two previously known species, was collected from a polychaete tube near the Yaeyama Marine Park Research Station in the Yaeyama Islands, southwest of Okinawa, Japan.

This paper gives a description of this new species of Aphanodactylus and a diagrammatic key to the subfamilies of the Pinnotheridae and the genera of the Asthenognathinae in Japan. The specimen has been deposited in the National Science Museum, Tokyo, under the accession number NSMT-Cr 12484.

\section{Aphanodactylus loimiae sp. nov.}

[Japanese name: Koyubi-pinno]

(Figs. 1, 2)

Material examined: Holotype (NSMT-Cr 12484) ovigerous female with carapace length (CL) $7.9 \mathrm{~mm}$ and width (CW) $13.9 \mathrm{~mm}$, from a tube of the terebellid polychaete Loimia ingens Grube, 1878 , collected by $\mathbf{F}$. Iwase, June 28, 1988. Type locality: ca. $3 \mathrm{~m}$ depth off Kuroshima Island, the Yaeyama Islands, Japan, $24^{\circ} 14^{\prime} \mathrm{N}, 123^{\circ} 59^{\circ} \mathrm{E}$.

Etymology: The specific epithet was formed from the generic name of the host terebellid 


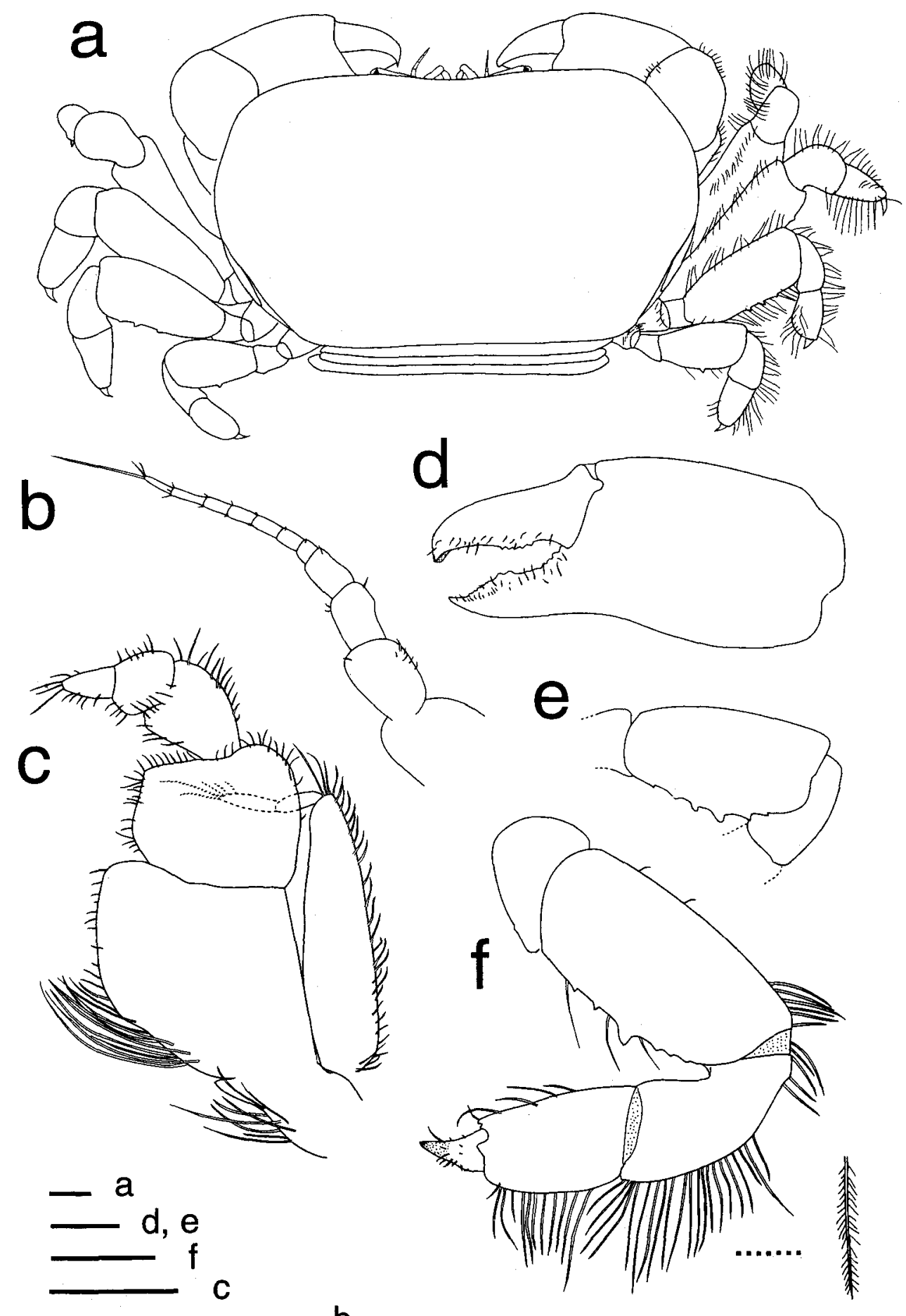

Fig. 1. Aphanodactylus loimiae sp. nov., holotype ovigerous female (NSMT-Cr 12484). a: whole animal in dorsal view, setae of appendages only shown on right side, b: antenna, c: maxilliped 3 , d: left cheliped, e: merus of walking leg 3, f: walking leg 4 with detail of seta. Scale bar $=1 \mathrm{~mm}$. 

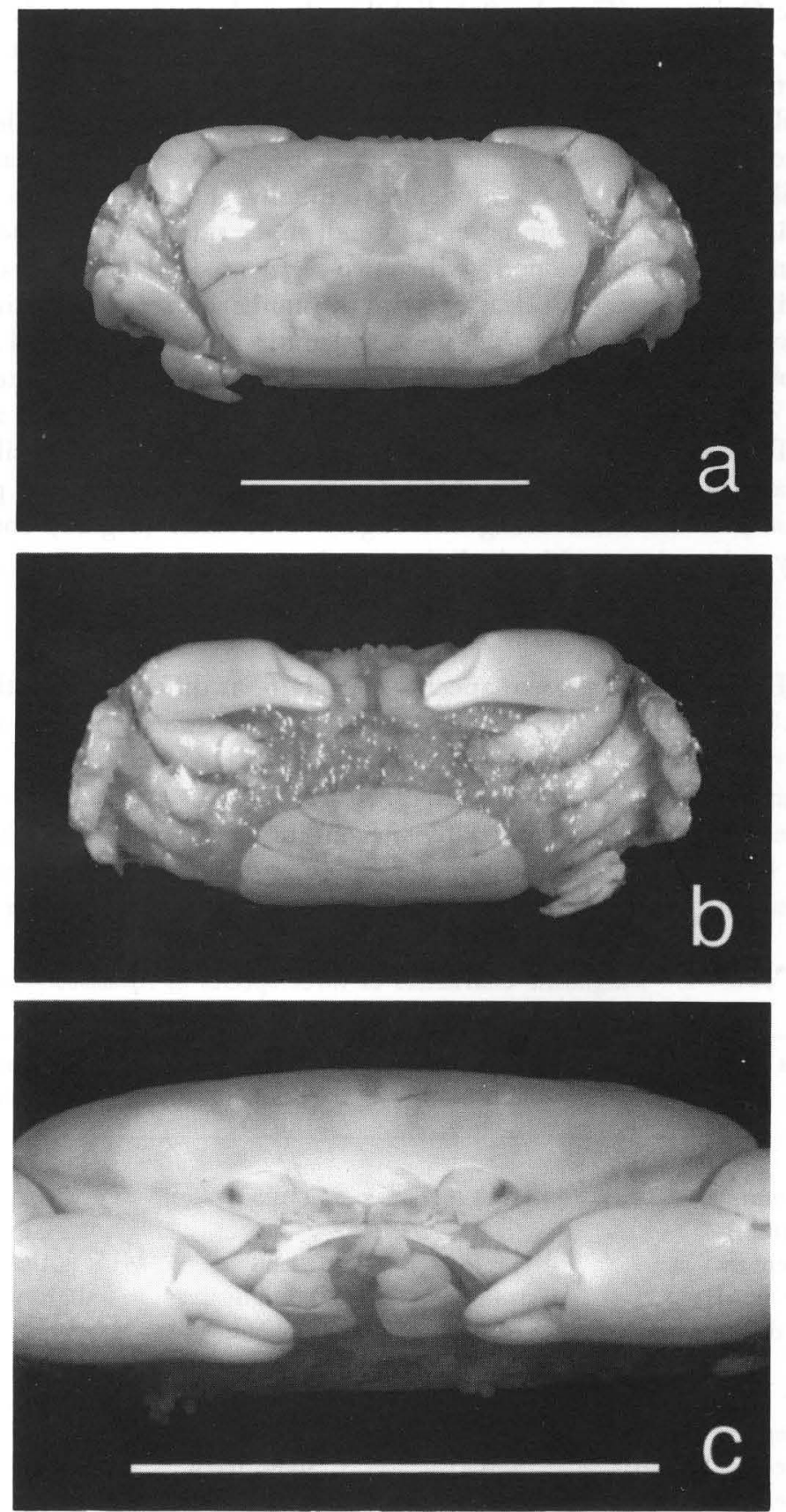

Fig. 2. Aphanodactylus loimiae sp. nov., holotype ovigerous female (NSMT-Cr 12484). Photographs in dorsal (a), ventral (b), and frontal view (c). Scale bar $=10 \mathrm{~mm}$. 
polychaete Loimia.

Description: Carapace (Figs. 1a, 2a) slightly subquadrate, transversely elongated, about 1.76 in CW:CL ratio. Anterior border of carapace almost straight, but slightly deflexed in middle portion. Surface of carapace smooth. Eye-stalks small, oval in frontal view. Antennule folded into a groove. Antenna (Fig. 1b) minute, peduncle four-segmented, and flagellum consisting of seven segments with a long seta and two small setae on distal segment. Maxilliped 3 (Fig.1c) oriented longitudinally (Fig.2c), ischium distinctly longer than merus, and palp segments jointed end to end; inner side of merus and ischium fringed with long, plumose setae; exopod with two-segmented flagellum with long distal setae. Cheliped (Fig. 1d) smooth, but carrying a number of setae on its inner margin and on edges of movable and immovable fingers; length of palm about 1.5 times that of fingers. Meri of walking legs 1-3 almost equal in length and with 4-6 teeth on posterior border (Fig.le), while those of walking legs 4 with a well developed tooth and two vestigial ones (Fig.1f). Dactyli of walking legs remarkably tiny and almost invisible, as suggested by the generic name (Gk. $\alpha \phi \alpha v \eta \varsigma=$ invisible + dactylus): shorter than $1 / 3$ of propodus. Each leg with rows of plumose setae along the edges. Abdomen (Fig.2b) consisting of seven segments. Body colour ivory-white in living specimen.

Remarks

The CW:CL ratio of the present specimen $(=1.76)$ is different from those of $A$. sibogae $(=1.88)$ and $A$. edmondsoni $(=1.69)$. The present species differs from $A$. sibogae in lacking two pairs of surface pits on the carapace and in the large number of segments of the antennal flagellum: $2-3$ and 7 segments in $A$. sibogae and A. loimiae, respectively. Another congener, $A$. edmondsoni, is distinguished by the outline of carapace and the posterior teeth on its walking legs 1-3: a large triangular spine instead of 5-6 spines in the present species. Edmondson (1962) stated that the walking leg 4 of $A$. edmondsoni was armed with

Table 1. Diagnostic characters of three species of Aphanodactylus

\begin{tabular}{|c|c|c|c|}
\hline Characters & $\begin{array}{l}\text { A. loimiae } \\
\text { This study }\end{array}$ & $\begin{array}{l}\text { A. sibogae } \\
\text { Tesch (1918) }\end{array}$ & $\begin{array}{l}\text { A.edmondsoni } \\
\text { Rathbum (1932) }\end{array}$ \\
\hline \multicolumn{4}{|l|}{ Carapace: } \\
\hline width $(\mathrm{mm})$ & 13.9 & 11.25 & 16.2 \\
\hline length (mm) & 7.9 & 6 & 9.6 \\
\hline width/length & 1.76 & 1.88 & 1.69 \\
\hline anterior border & straight & straight & slightly convex \\
\hline pits on dorsal surface & absent & present & absent \\
\hline \multicolumn{4}{|l|}{ Antenna: } \\
\hline flagellar segments & 7 & $2-3$ & 10 \\
\hline \multicolumn{4}{|l|}{ Walking legs: } \\
\hline merus teeth (1st-3rd) & $4-6$ & some teeth & 1 \\
\hline merus teeth $(4 \mathrm{th})$ & $1+2 \mathrm{v}$ & ? & 2 \\
\hline Locality: & $\begin{array}{l}\text { Kuroshima Is. } \\
\text { [Japan] }\end{array}$ & $\begin{array}{l}\text { Sumbawa Is. } \\
\text { [Indonesia] }\end{array}$ & $\begin{array}{l}\text { Oahu Is. } \\
\text { [Hawaii] }\end{array}$ \\
\hline Host: & Loimia ingens & Loimia sp.* & Loimia medusa \\
\hline
\end{tabular}

v: vestigial

*Possibly L. ingens, judging from Caullery (1944) 
two small teeth on lower border of the merus, while there are prominent tooth and two vestigial ones in A. loimiae. The diagnostic characters of the three species of Aphanodactylus are summarized in Table 1.

Other than the present genus, close similarity has also been noted to a species of the pinnotherelinid genus Pinnixa. Serène (1964) commented on the similarities found in Aphanodactylus and Pinnixa brevipes H. Milne Edwards, 1853 and stated, "Cependant brevipes a les pattes ambulatoires beaucoup plus longues comparativement à celles de $A$. sibogae et c'est une espèce différente qui justifie une nouvelle description avec figure d'après le type." Detailed information on the type specimen of $P$. brevipes is required before any conclusions can be drawn.

The present crab was found in a tube of the sessile polychaete Loimia just as $A$. sibogae was. According to Edmondson (1946), A. edmondsoni lives in the shelly tube of a large terebellid worm, and Schmitt et al. (1973) suggested "Loimia medusa (Savigny)" for this worm which is commonly found around Hawaii. No other host animals have been known for Aphanodactylus (Table 1). It is possible that the large tubes of Loimia provide a good refuge for commensal crabs with a smooth and transversely elongated carapace. In fact, the pinnotherinid species Sakaina japonica Serène, 1964, which has similar external morphology to species of Aphanodactylus, lives within the tubes of L. medusa (Yamaguchi et al., 1976; Konishi, 1981). Caullery (1944) noted that commensal anomuran crabs of the genus Polyonyx were commonly found in the tubes of L. ingens.

Aphanodactylus loimiae is the third record and species of its genus in the world. The subfamily Asthenognathinae of Japan now consists of three genera. Up-dated keys to the pinnotherid subfamilies and the asthenognatinid genera of Japan are given below, and Fig. 3 reproduces the same information diagrammatically.

Key to the subfamilies of the Pinnotheridae in Japan.

Fla. Orbits transverse in the usual position, invisible in dorsal view..... F2

F1b. Orbits and eye-stalks parallel longitudinally, wholly visible in dorsal view Subfamily Xenophthalminae

F2a. Ischium and merus of maxilliped 3 separated. F3

F2b. Ischium and merus of maxilliped 3 fused to a single piece

Subfamily Pinnotherinae

F3a. Ischium of maxilliped 3 smaller than merus, palp often larger than ischium-merus Subfamily Pinnotherelinae

F3b. Ischium of maxilliped 3 larger than merus, palp smaller than ischium-merus Subfamily Asthenognathinae

Key to the genera of the Asthenognathinae in Japan

G1a. Merus of maxilliped 3 slightly shorter than ischium, palp segments jointed end to end

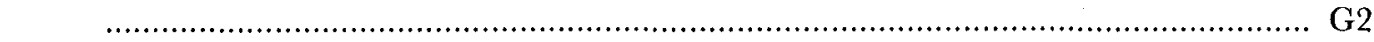

Glb. Merus of maxilliped 3 as long as ischium, dactylus of palp jointed to inner border of protopod Tritodynamia

G2a. Dactylus of walking leg 4 not considerably reduced, longer than $1 / 2$ of propodus; carapace roughly hexagonal ........................................................ Asthenognathus

G2b. Dactylus of walking leg 4 considerably reduced in size, shorter than $1 / 3$ of propodus; carapace subquadrate Aphanodactylus 


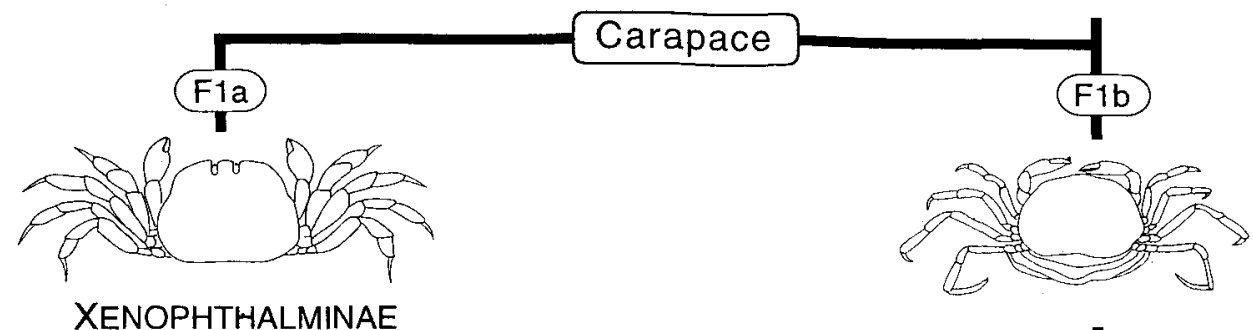

XENOPHTHALMINAE

Maxilliped 3

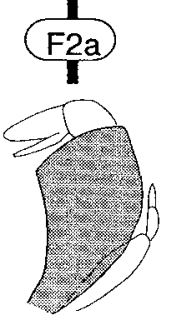

PINNOTHERINAE

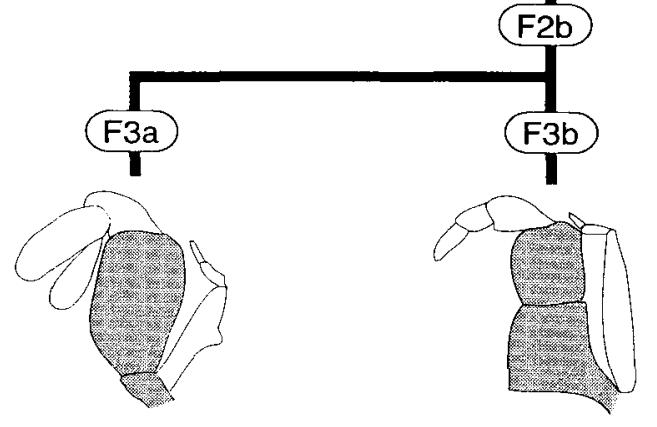

PINNOTHERELINAE AsthENOGNATHINAE

\section{Maxilliped 3}

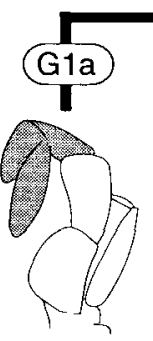

Tritodynamia

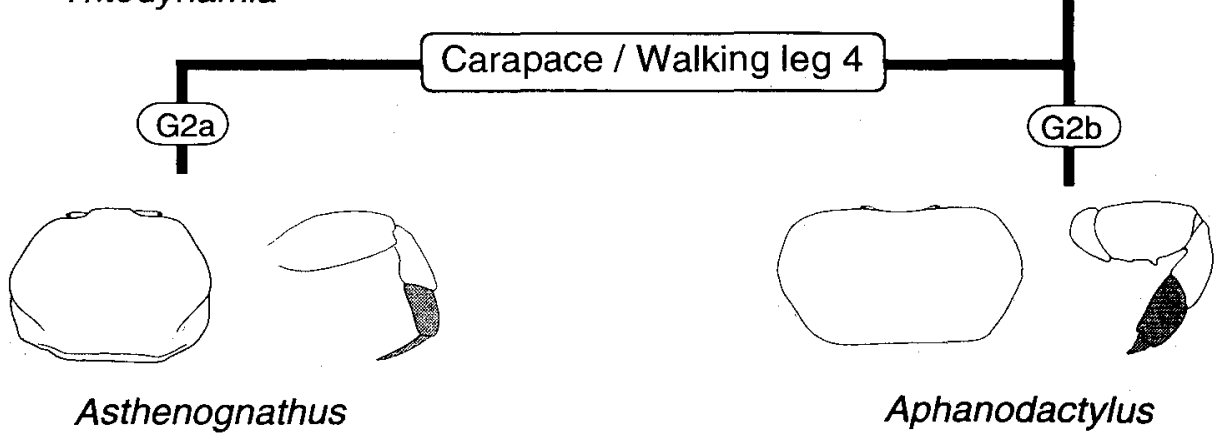

Fig 3. Diagrammatic key to pinnotherid subfamilies and asthenognathinid genera of Japan. Abbreviations on the various branch segments correspond to the headers of the key in the text. Diagnostic parts are indicated by hatching. The figures of Xenophthalmus, Tritodynamia, and Asihenognathus are redrawn from Sakai, 1976. 


\section{Acknowledgements}

We express our sincere gratitude to Mr. F. Iwase of Stella-Chemifa Corporation for collecting the material and Dr. H. Uchida of the Sabiura Marine Park Research Station for identifying the polychaete worm. Dr. H. Takahashi Prof. Emer. of Hokkaido University kindly provided us a literature. Our cordial thanks also due to Dr. M.J. Grygier of the Lake Biwa Museum for critical reading of the manuscript and Dr. M. Takeda of the National Science Museum for his encouragement during the study.

\section{References}

Caullery, M. 1944. Polychètes sédentaires de l'expédition du Siboga. Ariciidae, Spionidae, Chaetopteridae, Chlorhaemidae, Opheliidae, Oweniidae, Sabellariidae, Sternaspidae, Amphictenidae, Ampharetidae, Terebellidae. Siboga-Expeditie, 24i, 204 pp.

Edmondson, C.H. 1946. Reef and shore fauna of Hawaii. Occasional Papers of the Bernice Pauahi Bishop Museum, Special Publication 22: 1-381.

Edmondson, C.H. 1962. Hawaiian Crustacea: Goneplacidae, Pinnotheridae, Cymopoliidae, Ocypodidae and Gecarcinidae. Occasional Papers of the Bernice Pauahi Bishop Museum 23: 1-23.

De Haan, W. 1835. Crustacea. In: F. von Siebold, Fauna Japonica. 244 pp. 55 pls.

Miyake, S. 1983. Japanese crustacean decapods and stomatopods in color. Vol. II. Brachyura. Hoikusha, Osaka. 261 pp. 56 pls. [In Japanese]

Konishi, K. 1981. A description of laboratory-reared larvae of the pinnotherid crab Sakaina japonica Serène (Decapoda, Brachyura). Journal of Faculty of Science, Hokkaido University, Series VI, Zoology 22: 165-176.

Konishi, K. 1996. Some topics on pea crabs of Japan. Cancer, 5: 15-21. [In Japanese]

Rathbun, M.J. 1932. A new pinnotherid crab from the Hawaiian Islands. Journal of the Washington Academy of Sciences 22: 181-182.

Sakai, T. 1976. Crabs of Japan and adjacent seas. xxix +773 pp. (English part), 461 pp. (Japanese part), 16 pp. +251 pls. Kodansha, Toḱyo.

Schmitt, W.L., McCain, J.G., and Davidson, E.S. 1973. Crustaceorum catalogus. Pars 3. Decapoda I. Brachyura I. Fam. Pinnotheridae. Dr. W.Junk B.V., 160 pp.

Serène, R. 1964. Papers from Dr. Th. Mortensen's Pacific Expedition 1914-1916 80. Goneplacidae et Pinnotheridae. Videnskabelige Meddelelser fra Dansk Naturhistorisk Forening København 126: 181-282.

Tesch, J.J. 1918. The Decapoda Brachyura of the Siboga Expedition. II. Goneplacidae and Pinnotheridae. Siboga-Expeditie, 39c, 147 pp., pls. 7-18.

Yamaguchi, T., Takeda, M., and Tokudome, K. 1976. A list of crabs collected in the vicinity of the Aitsu Marine Biological Station and a preliminary report on the cheliped asymmetry of the crabs. Calanus, 5: 31-46. [In Japanese] 